\title{
Estimation of Non-Genetic Parameters for Reproduction and Production Traits of Holstein Friesian Dairy Herd at Elfora Cheffa Dairy Farm, Amhara Region, Ethiopia
}

Wubshet Woldegiorgis Kassa ( $\sim$ lwkwk27@gmail.com )

Wollo University

Yosef Tadesse Mengesha

Haramaya Hniversity

Aynalem Haile Gebele

ICARDA: International Center for Agricultural Research in the Dry Areas

\section{Research}

Keywords: Cheffa dairy farm, Non-genetic, Productive traits, Reproductive traits

Posted Date: November 3rd, 2020

DOI: https://doi.org/10.21203/rs.3.rs-97802/v1

License: (c) (1) This work is licensed under a Creative Commons Attribution 4.0 International License.

Read Full License 


\section{Abstract}

Background:- The study was conducted at Cheffa dairy farm with the objective of estimating the effects of none-genetic factors on Age at First Service (AFS), Age at First Calving (AFC), Calving Interval (Cl), Days Open (DO), Number of Service per Conception (NSC), Lactation Length (LL) and adjusted 305 days milk yield (305-dMY). A total of 2343 records were collected from 123 cows and 13 sires' progenies having greater than 93.75 \% HF blood levels through the period from 1996 to 2014 for evaluation. Independent variables were birth year and season, calving year and season and parity while AFS, AFC, Cl, DO, NSC, LL and 305-dMY were dependent variables. SAS Version 9.1 software used for data analysis.

Results:- The results indicated that year of birth had highly significant $(p<0.01)$ and significant $(p<0.05)$ effect on AFS and AFC respectively. Year of calving had highly significant $(p<0.01)$ effect on $\mathrm{Cl}$ and 305$\mathrm{dMY}$ and significant $(\mathrm{p}<0.05)$ effect on DO and NSC. Season of calving had significant $(p<0.05)$ effect on $\mathrm{Cl}$ and 305-dMY. Longest records of $\mathrm{Cl}$ and highest records of 305-dMY were exhibited in short rain season while, shortest and lowest records of $\mathrm{Cl}$ and 305-dMY were recorded in dry and long rain seasons respectively. Parity had highly significant $(p<0.01)$ effect on $\mathrm{Cl}, \mathrm{DO}, \mathrm{NSC}$ and $305-\mathrm{dMY}$ and significant $(p<0.05)$ effect on LL. Longest value of $\mathrm{Cl}, \mathrm{DO}$ and $\mathrm{LL}$ were observed in $1^{\text {st }}$ parity and highest value of NSC and highest value of 305-dMY were recorded in $7^{\text {th }}$ and $5^{\text {th }}$ parity respectively. The shortest value of $\mathrm{Cl}, \mathrm{DO}, \mathrm{LL}$ and lowest value of $305-\mathrm{dMY}$ was recorded in $9^{\text {th }}$ parity while shortest value of NSC was recorded in $1^{\text {st }}$ parity.

Conclusions:- This study revealed, genetic performance of dairy breed in the study area was influenced by environment but selecting adapted animal from the herd and better management may improve all aspect of productivity. Hence, well record keeping, better management practice, non-genetic performance evaluation of economically important dairy traits and investigation of selection index were a prerequisite to improvement productivity of the herd and to run profitable dairy enterprise.

\section{Introduction}

Ethiopia is one of the sub-Saharan Africa's developing countries with a large potential in livestock population. However, dairy industry is not developed as that of other east African countries such as Kenya, Uganda and Tanzania (Hunduma, 2013).

The productivity of dairy cattle breeds depends mainly on their reproductive and production performance of genetic traits and non-genetic/environmental factors. Reproductive performance is a characteristic of outstanding importance in dairy cattle business (Hunduma, 2013). The productivity of cattle depends largely on their reproductive performance and reproduction is an indicator of reproductive efficiency. An important prerequisite for the sustainability of a dairy production system is reproductive performance. Therefore, estimating non-genetic parameters for various livestock traits has been a main issue of animal breeding (Hyon, 2003). The relatively poor potential of the local dairy cattle in the tropics necessitates the 
importation of exotic high milk producing breeds in order to fill the gap between milk consumption and actual demand (Belete, 2006).

Jersey and Holstein-Friesian breeds are most common highly productive exotic dairy cattle breeds that were introduced in Ethiopia, and are important sources of milk and income, especially in urban area. Despite to this fact, specifically after the animals are introduced, their reproductive and productive performances are not well documented in an appropriate manner at the locations where the breed is distributed (Hunduma, 2013).

The performance of a population can be studied by considering the relative importance of heredity and environmental factors affecting the overall phenotypic and genetic variances, which summarizes the nature of that population. Pertinent to the effective use, genetic variability is knowledge of the genetic and environmental relationships among the characters which include heritability, repeatability, breeding value of the characters and the genetic, phenotypic and environmental correlations among them (Khalid et al., 2001).

Improvement of the already existing indigenous genotypes, their crosses with highly productive exotic breeds or their replacement with superior breeds; depends on the knowledge of the attributes of these genotypes and the socio-economic factors that affect production in those environments (Kelay, 2002.). Understanding these factors and their influence on cattle productive and reproductive performance are important in planning of management scheme and selection decisions.

Previously Gebeyehu (2005) has undertaken a study on various productive and reproductive performances of HF dairy animals at Cheffa Dairy farm, in which the current study was carried out. His Study was carried out before 11 years ago which is impossible to evaluate the current herd and not cover most non-genetic factors that affect the performance of the animal in the farm. Moreover, there is a need to include recent animals' performance data for timely recommendations for the improvement of the farm. Therefore, with the above background this study was undertaken with the following objectives.

\section{General objective:}

To identify and estimate effect of non-genetic factors on production and reproduction traits of Holstein Friesian dairy cattle in ELFORA Cheffa dairy farm, Ethiopia.

\section{Methods}

\section{Description of the Study Area}

The study was conducted in Amhara Regional State of Oromia special administration Zone Dawa Cheffa District Woledi Village at ELFORA Cheffa Dairy Farm, which is found North- East part of the country at $360 \mathrm{~km}$ towards the Northern part of the capital of Addis Ababa. The farm is located $40 \mathrm{~km}$ from Dessie to Addis, at $10^{\circ} 50^{\prime} 39.3^{\prime \prime}$ latitude and $39^{\circ} 48^{\prime} 43.9^{\prime \prime}$ longitudes with an altitude of 1466 m.a.s.l. The farm 
site is found in Cheffa valley adjacent to South Wollo zone. Based on the fifteen years metrological data the three defined seasons in the area were short rains (February to May); long rains (June to September) and dry season (October to January). A bimodal rainfall pattern is the feature of the area with an annual average rainfall of $1001.82 \mathrm{~mm}$ of which $23.6 \%$ falls in short rainy season. The average maximum and minimum temperature was $30.23^{\circ} \mathrm{C}$ and $13.5^{\circ} \mathrm{C}$, respectively.

\section{Study Animals and Management}

Cheffa ELFORA dairy farm started with Friesian-Boran crossbred dairy cows that were established from Ethiopian Boran dams and pure Holstein-Friesian bulls (from United States of America) before 42 years ago.

However, this research comprises the data collected only from dairy cows whose HF blood level was above $93.75 \%$ and those who were produced from $\mathrm{F}_{3}$ and their subsequent offspring dams and pure Holstein-Friesian bulls. In this case the data collected were considered as all from Holstein-Friesian dairy cows.

\subsection{Feed and feeding practice:}

Feeding system was by both carry and grazing of all steers, heifers, dry and lactating cows with the different time duration. All group of animals were allow to graze on native pasture throughout the year but, milking cows were allowed to graze on native pasture only during long and short rain seasons from 6:30 to 10:00 am and supplied with native grass hay, alfalfa, and concentrate feed prepared at the farm by mixing (formulated from) $70 \%$ nouge seed cake, $15 \%$ maize/sorghum, $13 \%$ third grade of mung bean and corncob and $2 \%$ common salt on return to the barn.

This concentrate feed is given for all animal groups based on the animal's age, physiological status and sex difference without considering amount of milk production and it was provided $5 \mathrm{~kg}, 3 \mathrm{~kg}$, and $2 \mathrm{~kg}$ formulated feed per day for breeding bull, lactating and pregnant cow, and calves respectively. All animals had free access to water and newborn calves were taken away from their dams soon after birth and use colostrum immediately after birth and there after allowed to bucket-feeding 4 and 6 liter of milk per day for male and female calves before weaning till the age of 90 and 120 days respectively.

\subsection{Health care and management:}

Most common infectious disease suspected and sometimes confirmed by laboratory were Lumpy Skin Disease (LSD), Foot and Mouth Disease (FMD), Anthrax, Blackleg, Bovine Pasteurollosis (BP), Contagious Bovine Pleuro pneumonia (CBPP) and most frequently Mastitis. Based on the suspected or confirmed cases, appropriate drugs for corresponding treatment was given by veterinarians in the mini clinic for animals' health, established in the farm. Regular vaccination against LSD, FMD, Anthrax, Blackleg, BP, and CBPP were given and treatments provided when incidence of various cases were observed. 
Anthrax and LSD vaccination were given in August every year for all animals above 6 months old. However LSD was rarely observed and in the history of the farm its incidence was only once.

Blackleg and BP were vaccinated every March to May per year and if there is an outbreak, vaccination was given again in 6 month difference for all animals above 6 month old. Vaccines for CBPP were given in January every year but, FMD were vaccinated during an outbreak or before an outbreak which was observed in the neighboring districts. Milk samples were submitted for tuberculosis examination when required and during suspected cases.

Every year, during September and June, animals for internal and external parasites were dewormed and sprayed respectively as mass treatment. Common prevalent internal parasites in the farm were Liver fluke, Schistosomia and some other Gastro Intestinal Parasites (GIP) and most prevalent external parasites were ticks (especially hard tick), Mange-mites, Lice, Dermatophyllosis and Ring-worms.

\subsection{Breeding management:}

Animals in heat were routinely followed throughout a day but, regularly early in the morning after milking, in the resting period at noon, and in the afternoon before milking. Most of the cows were served at first observed heat after calving but, according to the length of DO observed; cows were served at their second or third heat detection. Mating was natural in most cases and rarely artificial insemination (Al) was used. Based on the time included in data records and regardless of heat detection, mating system and sire fertility performance; cows conceiving rate or fertility rate (FR) were $79.4 \%$. Pregnant cows were managed separately during the trimester; they are not allowed to graze far away from the farm and they calved in separate calving pens. Calves were separated from their dams' immediately after birth and allowed to colostrum feeding. Male calves were castrated within one month of age after birth and kept as a steer until marketed. Culling was practiced as a result of (based on) disease, low milk production, poor reproductive rate and old age. During the time of the data included; and without considering any environmental and genetic factors, the average lifetime (longevity) of animal in the farm was 2962.1days. Most management activities, however, were continued fairly at a regular interval.

\subsection{Milking time and milk yield:}

Cows were calved within an average pregnancy length (PL) and dry period (DP) of 274.1 and 147 days respectively and they were hand-milked twice daily at 4:00 am and 4:00 pm nearly in 12 hour interval. The farm average daily milk yield (ADMY) and LMY was 7.3 and 2622.9 liters respectively which were produced from an average $L L$ of 328.3 days with in an average ambient temperature of $21.98{ }^{\circ} \mathrm{C}$ and with an average relative humidity $(\mathrm{RH}) 54.7 \%$.

\subsection{Housing:}

Since the farm site is adjacent to the Borkena River which drains in to the Awash River in the Cheffa rift valley; open loose type of house is used in the farm. However; maternity, calf, isolation and bull pens were close type of house with one-third part of the wall height is open. Housing is therefore based on sex, 
physiological and health status, and age category (which were for calves), calving (maternity), isolation and bull pen. In this way calves up to 45 to 65 days, heifers and steers up to six months and those animals greater than six month old were allocated in separate room. There were milking rooms adjacent with the bull pen. Administration and gust house, milk product processing room, veterinary clinic and spraying room were part of the farmstead.

\section{Sources of Data and Method of Data Collection}

At Cheffa ELFORA Dairy Farm, there are detail information on different recording books (herd books) these includes animals identification number (ID No for sire, dam and newly born calves), date of birth, date of service, calving date, number of calving (parity), calving ease, abortion and still birth. Similarly incidence of common infectious and parasitic diseases (mostly clinical cases), vaccination and vaccination schedules, deworming and its schedules, milk production (daily, monthly, and LMY), date off dry, feed and feeding skim all up to culling or death of the animals were recorded based on prepared formats for each events.

Therefore, the data was obtained as a secondary records from all available records in the farm for reproductive and productive traits performance analysis of dairy cattle under study area which started from calving to the animals were culled from the herd either by the loss of reproductive or productive performance or by any internal as well as external disease factors. The data was organized with greatest care for its quality and soundness.

In addition to those records found in the farm; all the necessary information were assessed and organized thoroughly while the data collection activity was performed.

Those data sources or information from the available records were collected and organized by animal science professionals with strong collaboration of the farm workers as per their job description, position and profession. This data comprises most available and necessary information starting from 1996 to 2014 which was 19 years records of dairy cattle having HF blood level were $93.75 \%+$.

Therefore, cows involved in this study were not fully HF breeds rather all they have above $93.75 \% \mathrm{HF}$ blood which they were considered as HF dairy breed in the analysis of the study.

In this case information about herd productive and reproductive status, feed and feeding skims, the overall management activities, most common disease and parasite prevalence, and their control and protection mechanism were well collected and organized based on records available, observation and discussion with the farm expertise.

\section{Data Extraction for None-Genetic Factors Estimation}

This study consists of lactation records of 483 cows born from 1996 to 2012 and gave birth between 1998 and 2014 to estimate the effects of non-genetic effects of productive and reproductive traits performances of the study animals (Table 1). All required and available information were extracted from 
the collected and observed data. A total of 13 sires purchased from Holleta bull dam station were included in all lactation records of non-genetic effects of productive and reproductive traits performances. Nineteen years thoroughly recorded documents were taken to maximize the accuracy and precision of parameters estimation.

The study of non-genetic effect estimation was fully depends on the available recorded data but it focused on some economically important reproduction and production traits including AFS, AFC, NSC, $\mathrm{Cl}$, DO, LL and 305-dMY and taking some fixed effects. In fact, non-genetic factors affecting the reproductive and productive performance of dairy cattle were numerous in number and vary according to the breed type, environmental condition and management activity of the business owner.

Table 1. Characteristics of the data set used for the analysis of the study

\begin{tabular}{|l|c|}
\hline Description & Total \\
\hline Records in data & 2343 \\
\hline Cows in data & 123 \\
\hline Sires in data & 13 \\
\hline Years covered in the study (1996-2014) & 19 \\
\hline Seasons (dry season, short rain season and long rain season) & 3 \\
\hline Parity (1 to 9+) & 9 \\
\hline Traits (AFS, AFC, NSC, Cl, DO, LL and 305-dMY) & 7 \\
\hline Observed environmental effects (birth year/season, calving year/season and parity) & 5 \\
\hline Total lactation record & 483 \\
\hline
\end{tabular}

$\mathrm{AFS}=$ Age at first service, $\mathrm{AFC}=$ Age at first calving, $\mathrm{NSC}=$ Number of service per calving, $\mathrm{Cl}=$ Calving interval, DO = Days open, LL = Lactation length, 305-dMY = Adjusted 305 days milk yield

\section{Data Analysis and Interpretation}

Data collected were retrospective for both reproductive and productive performance estimation. The data collected based on the information from records as a secondary data was summarized by using descriptive statistics such as percentages, mean, frequency and standard deviations.

Those collected data were analyzed by using general linear model (GLM) to estimate the effect of nongenetic factors (fixed effects) like birth year/season, calving year/season and parity on the performance of reproductive and productive traits of dairy cows. Conversion of lactation milk yield to adjusted 305 days of milk yield was calculated by the formula stated by (Wiggans and Dickinson, 1985). 
The data was entered into Microsoft Excel, 2007 software in order to transfer the data and a logarithmic scaling of the recorded data was carried out for data transformation, as suggested by earlier studies, to achieve a data with more normal distribution and to minimize the error due to outlier records during nongenetic parameter estimation.

Non-genetic parameters estimation and conversion of adjusted 305 days milk yield were respectively analyzed by using general linear model (GLM) and regression procedure of Statistical Analysis System (SAS) software version 9.1 (Chevell, 2008) and Duncan Multiple range Test (DMRT) was used to mean comparison of significant fixed effects.

\section{Models Used for Data Analysis}

The data obtained from records as secondary data for traits AFS, AFC, NSC, Cl, DO, LL and 305-dMY were analyzed using general linear model and regression procedures.

1. General linear model (GLM): To estimate the effect of non-genetic factors like year of birth /season, year of calving /season and parity on AFS, AFC, NSC, Cl, DO, LL and 305-dMY and the variance components; the following GLM statistical model was used.

i) Statistical Model for Analysis of AFS and AFC: To estimate the effect of non-genetic factors (year and season of birth) on AFS and AFC

$A_{i j}=\mu+Y_{i}+S_{j}+e_{i j}$

Where: $A_{i j}=A F S$ and AFC of $i j^{\text {th }}$ cow

$\mu=$ overall mean;

$Y_{i}=$ the effect of $i^{\text {th }}$ year of birth $(I=1996$ to 2012$)$

$S_{j}=$ the effect of $j^{\text {th }}$ season of birth (dry, short rain and long rain seasons)

$\mathrm{e}_{\mathrm{ij}}=$ random error associated with $\mathrm{ij}^{\text {th }}$ observation

ii) Analysis of NSC, Cl, DO, LL and Adjusted 305dMY: To estimate the effect of non- genetic factors (year and season of calving and parity) on Cl, DO, NSC, LL and 305-dMY.

$A_{i j k}=\mu+Y_{i}+S_{j}+P_{k}+e_{i j k}$

Where: $A_{i j k}=N S C, C l, D O, L L$ and Adjusted 305dMy of ijk ${ }^{\text {th }}$ cow

$\mu=$ overall mean;

$Y_{i}=$ the effect of $i^{\text {th }}$ year of calving ( $I=1998$ to 2014) 
$S_{j}=$ the effect of $j^{\text {th }}$ season of calving (dry, short rain and long rain seasons)

$P_{k}=$ the effect of $k^{\text {th }}$ parity $(k=1$ to $9+)$

$\mathrm{e}_{\mathrm{ijk}}=$ random error associated with $\mathrm{ijk}^{\mathrm{th}}$ observation

2. Regression model: To convert lactation milk yields milked from shorter than 305 days of LL of individual cows to adjusted 305 milking days.

$$
\hat{\mathrm{Y}}_{305}=\mathrm{Y}_{\mathrm{DDA}}+\left(\hat{\mathrm{Y}}_{\mathrm{D}}\right)(305-\mathrm{DIM})
$$

Where: $\quad \widehat{\mathbf{Y}}_{\mathbf{s o s}}$ : = Projected 305-day yield,

$\mathbf{Y}_{\mathbf{D n M}}$ = yield for the partial record,

$\hat{\mathbf{Y}}_{\mathbf{D}}$ = estimated average daily yield for the remainder of the lactation

305-DMM = days remaining.

\section{Result}

Non-Genetic Factors for Reproduction and production Traits

The results of non-genetic factors (birth year/season, calving year/season and parity) for reproductive and productive traits of the cows are showed in Table 2. 
Table 2

Reproductive and productive traits performance of HF cows in the study area

\begin{tabular}{|c|c|c|c|c|c|c|c|}
\hline \multirow[t]{2}{*}{ Observed traits } & \multirow{2}{*}{$\begin{array}{l}\text { Obser- } \\
\text { vation }\end{array}$} & \multirow{2}{*}{$\begin{array}{l}\text { Overall } \\
\text { mean } \pm S E\end{array}$} & \multicolumn{2}{|l|}{ Birth } & \multicolumn{2}{|c|}{ Calving } & \multirow[t]{2}{*}{ Parity } \\
\hline & & & Year & Season & Year & Season & \\
\hline $\begin{array}{l}\text { Age at first service } \\
\text { (months) }\end{array}$ & 123 & $30.5 \pm 0.60$ & ** & ns & & & \\
\hline $\begin{array}{l}\text { Age at first calving } \\
\text { (months) }\end{array}$ & 123 & $\begin{array}{l}39.76 \pm \\
0.67\end{array}$ & * & ns & & & \\
\hline $\begin{array}{l}\text { Number of services per } \\
\text { conception(ratio) }\end{array}$ & 483 & $1.6 \pm 0.05$ & & & * & ns & ** \\
\hline Calving Interval (days) & 360 & $\begin{array}{l}446.1 \pm \\
6.79\end{array}$ & & & ** & * & ** \\
\hline Days open (days) & 360 & $\begin{array}{l}181.7 \pm \\
7.01\end{array}$ & & & * & ns & ** \\
\hline Lactation length (days) & 447 & $\begin{array}{l}328.3 \pm \\
5.50\end{array}$ & & & ns & ns & * \\
\hline Adjusted 305dMY(liter) & 447 & $\begin{array}{l}2305.2 \pm \\
32.15\end{array}$ & & & ** & * & $\star \star$ \\
\hline
\end{tabular}

\section{Age at First Service (AFS) and Age at First Calving (AFC)}

The overall least squares means indicated that both reproductive traits of AFS and AFC are significantly $(P<0.01)$ and $(P<0.05)$ affected by year of birth respectively, while season of birth had non-significant effect on AFS and AFC. The effects of year of birth and season of birth on reproductive traits of AFS and AFC are presented in Table 3.

\section{Calving Interval (Cl) and Days Open (DO)}

Least squares means of $\mathrm{Cl}$ and $\mathrm{DO}$ for year and season of calving and parity are indicated in Table 4. In the current study, $\mathrm{Cl}$ was highly significantly $(P<0.01)$ affected by year of calving and parity and significantly $(P<0.05)$ affected by season of calving while, year of calving and parity showed significant $(P<0.05)$ and highly significantly $(P<0.01)$ effect on DO respectively and season of calving had nonsignificant effects on DO.

\section{Number of Service per Conception (NSC)}

Least-squares means (LSM $\pm \mathrm{SE}$ ) of number of service per conception (NSC) is indicated in Table 5. According to the present study; the overall least squares means indicated that the reproductive trait of NSC was significantly $(P<0.05)$ affected by year of calving and highly significantly $(P<0.01)$ affected by parity, while season of calving had non-significant effect on NSC. 


\section{Lactation Length (LL) and Adjusted 305 Days of Milk Yield (305-dMY)}

Least-squares means ( $L S M \pm S E$ ) of lactation length and adjusted 305 days of milk are presented in Table 6. According to the current study; the overall least squares means indicated that 305-dMY was highly significantly $(P<0.01)$ affected by year of calving and parity and significantly $(P<0.05)$ affected by season of calving, while LL was significantly $(P<0.05)$ affected by parity only.

\section{Discussion}

\section{Age at First Service (AFS) and Age at First Calving (AFC)}

The results of this study showed that the effect of year of birth on AFS and AFC was highly significant while season of birth had non-significant effect on both AFS and AFC. The significant effect of year of birth on AFS and AFC were in agreement with the reports of Yosef (2006) in Holleta dairy farms, Alewya (2014) in Holleta bull dam station and Genesis dairy farms, Haile (2014) in Alage dairy farm and Mengistu et al. (2016) in Ardaita dairy farm for Holstein dairy cows. The longer (poor) result for both AFS and AFC were recorded in 2007 and shorter AFS and AFC were recorded in 2011 and 2012 respectively (Table 3). The cause for the significant effect of year of birth on AFS and AFC might be due to changes in climatic conditions (in temperature, rainfall and relative humidity) during different years of birth (National Metrology Agency Kombolcha Branch). Gader et al. (2007), Besufekad (2008) and Alewya (2014) also describes the significant effect of year of birth on AFS and AFC might be due to changes in climatic conditions and feeding regimes during different year of birth.

Season of birth had non-significant $(P>0.05)$ effect on both AFS and AFC in the present study (Table 3). Non-significant effect of season of birth on AFC was also reported by Besufekad (2008) in Holleta bull dam station and Million et al. (2010) in Holleta, Stella and Dinkity dairy farms. On the contrary, the significant effect of season of birth on AFS and AFC was reported by Mengistu et al. (2016) in Ardaita dairy farm and Yosef (2006) in Holleta dairy farm respectively. Non- significant effect of season of birth on AFS and AFC might be due to effective use of native grass and some improved forages like Alfalfa and Rhodes grass by applying periodic irrigation and rotational grazing and also supply of ground water during the dearth time which might have hidden the effect of season on AFS and AFC. 
Table 3

Least-squares means $(\mathrm{LSM} \pm \mathrm{SE})$ for the effect of year of birth and season on age at first service and age at first calving

\begin{tabular}{|c|c|c|c|}
\hline & & AFS (Months) & AFC (Months) \\
\hline Source & $\mathrm{N}$ & $\mathrm{LSM} \pm \mathrm{SE}$ & $\mathrm{LSM} \pm \mathrm{SE}$ \\
\hline Overall mean & 123 & $30.5 \pm 0.60$ & $39.76 \pm 0.67$ \\
\hline Year of birth & & ** & * \\
\hline 1996 & 5 & $32.5^{\mathrm{ab}} \pm 2.62$ & $41.9^{a b} \pm 2.65$ \\
\hline 1997 & 1 & $29.1^{\mathrm{ab}} \pm 00$ & $38.4^{\mathrm{ab}} \pm 00$ \\
\hline 1998 & 2 & $33.7^{\mathrm{ab}} \pm 7.05$ & $42.8^{\mathrm{ab}} \pm 7.20$ \\
\hline 1999 & 7 & $29.5^{\mathrm{ab}} \pm 1.91$ & $37.0^{\mathrm{ab}} \pm 4.09$ \\
\hline 2000 & 4 & $28.2^{\mathrm{ab}} \pm 2.20$ & $36.4^{\mathrm{b}} \pm 2.47$ \\
\hline 2001 & 17 & $27.8^{\mathrm{b}} \pm 1.75$ & $37.6^{\mathrm{ab}} \pm 1.88$ \\
\hline 2002 & 7 & $26.1^{b} \pm 0.34$ & $35.4^{\mathrm{b}} \pm 0.53$ \\
\hline 2003 & 10 & $27.3^{\mathrm{b}} \pm 1.36$ & $36.2^{b} \pm 1.47$ \\
\hline 2004 & 13 & $28.2^{\mathrm{ab}} \pm 1.05$ & $37.3^{\mathrm{ab}} \pm 1.04$ \\
\hline 2005 & 11 & $31.9^{\mathrm{ab}} \pm 1.28$ & $41.4^{\mathrm{ab}} \pm 1.04$ \\
\hline 2006 & 10 & $34.8^{\mathrm{ab}} \pm 1.80$ & $44.0^{\mathrm{ab}} \pm 2.37$ \\
\hline 2007 & 6 & $38.7^{a} \pm 2.61$ & $49.0^{\mathrm{a}} \pm 2.19$ \\
\hline 2008 & 14 & $34.4^{\mathrm{ab}} \pm 2.12$ & $44.0^{\mathrm{ab}} \pm 2.41$ \\
\hline 2009 & 8 & $30.3^{\mathrm{ab}} \pm 3.28$ & $39.8^{\mathrm{ab}} \pm 4.10$ \\
\hline 2010 & 4 & $27.7^{b} \pm 2.49$ & $36.9^{\mathrm{ab}} \pm 2.43$ \\
\hline 2011 & 2 & $25.3^{\mathrm{b}} \pm 0.55$ & $34.5^{\mathrm{b}} \pm 0.55$ \\
\hline 2012 & 2 & $26.9^{b} \pm 00$ & $33.2^{b} \pm 00$ \\
\hline Season of birth & & ns & ns \\
\hline
\end{tabular}

Means followed by the same super script do not differ significantly $(P>0.01)$ or $(P>0.05)$; ** $=$ Highly significant at $(P<0.01) ; *=$ Significant at $(P<0.05) ; N S=$ Non-significant; $N=$ Number of observation, $H F=$ Holstein-Friesian, Short rain season: February to may, Long rain season: Jun to September, Dry season: October to January 


\begin{tabular}{|c|c|c|c|}
\hline & & AFS (Months) & AFC (Months) \\
\hline Short rain season & 33 & $31.2 \pm 1.16$ & $40.3 \pm 1.27$ \\
\hline Long rain Season & 36 & $29.5 \pm 1.18$ & $38.9 \pm 1.30$ \\
\hline Dry Season & 54 & $30.6 \pm 0.88$ & $39.9 \pm 1.00$ \\
\hline \multicolumn{4}{|c|}{$\begin{array}{l}\text { Means followed by the same super script do not differ significantly }(P>0.01) \text { or }(P>0.05) ; * *=\text { Highly } y \text {, }(P \text { significant at }(P<0.01) ; *=\text { Significant at }(P<0.05) ; N S=\text { Non-significant; } N=\text { Number of observation, } \\
H F=\text { Holstein-Friesian, Short rain season: February to may, Long rain season: Jun to September, Dry } \\
\text { season: October to January }\end{array}$} \\
\hline
\end{tabular}

The overall mean age of heifers for AFS and AFC were $30.5 \pm 0.60$ and $39.76 \pm 0.67$ months (Table 3 ) with coefficient of determination $\left(R^{2}\right)$ of 0.27 and 0.30 and ranges from 18.4 to 49.7 and 26.8 to 63.2 months, respectively. Means of this study for AFS and AFC are longer than the previous findings of Alewya (2014) with 24.4 and 33.4 months for Holstein-Friesian heifers in Holleta Bull Dam Station and Genesis Farms, Ethiopia respectively. Similarly, findings from the current study were longer results than reported by Haile (2014) for AFS 27.1 and for AFC 37.1 months for Holstein-Friesian heifers in Alage dairy farm, Ethiopia. Shorter results of AFC for HF dairy cows as compared to the current result were 29.7, 30.9 and 29.8 months reported by Gader et al. (2007) in Sudan, Gwaza et al. (2007) in Cameron and Rahman and Alemam (2008) in the tropics respectively.

The current result for AFC was nearly in concordance to the previous findings of Million et al. (2010) and Gebeyehu et al. (2014) with 39.2 and 40.4 months, respectively for HF dairy cows in Holleta Bull Dam Station, in Ethiopia. Longer AFS and AFC with 34.1 and 43.8 months, respectively as compared to the present study were reported by Yosef (2006) for HF dairy cows in Holleta dairy farms in the highlands of central Ethiopia. These differences might be due to different breeding management, health care, environmental conditions like; temperature, rainfall and humidity, feeding management, and type and availability of basal feed resources at different locations and farms (Alewya, 2014). In this case inefficient breeding management (heat detection due to silent heat of heifers) and bulls' breeding efficiency may cause variation in AFC attainment. It might be also from HF blood group variation; since herds in the current study comprises greater than $93.75 \% \mathrm{HF}$ blood group. The optimum temperature of environmental air for European dairy cattle is between $10^{\circ}$ and $18^{\circ} \mathrm{C}$ and the ideal range for the relative humidity is between 60 and $70 \%$ as reported by Ozhan et al. (2001). Therefore, higher average temperature of $21.98{ }^{\circ} \mathrm{C}$ and lower average relative humidity of $54.7 \%$ in the current study area might be the cause for longer AFS and AFC.

\section{Calving Interval (Cl) and Days Open (DO)}

Significant effect of year of calving, season of calving and parity on $\mathrm{Cl}$ in the present study was similar to the previous study of Million et al. (2010) in Holleta, Stella and Dinkity dairy farms. The significant effect of year of calving on $\mathrm{Cl}$ were also in agreement with the previous reports of Yosef (2006) in Holleta dairy farm, Gebeyehu et al. (2007) in Stella Private Dairy Farm, Alewya (2014) in Holleta bull dam station and 
Genesis farm and Haile (2014) in Alage dairy farm. Similarly, significant effect of parity on Cl was described by Besufekad (2008) in Holleta bull dam station and Mengistu et al. (2016) in Ardaita dairy farm. However, non-significant effects of season of calving and parity on $\mathrm{Cl}$ were reported by Alewya (2014), Haile (2014) and Mengistu et al. (2016).

In agreement of the current study; the significant effect of year of calving on DO were previously reported by Yosef (2006), Gebeyehu et al. (2007), Million et al. (2010), Amene et al. (2011) in Alage dairy farm, rift valley of Ethiopia, Alewya (2014) and Haile (2014) and significant effect of parity on DO were supported by the previous studies of Besufekad (2008), Million et al. (2010) and Mengistu et al. (2016). To the contrary non-significant effects of year of calving and parity on DO were reported by Gader et al. (2007) in Sudan under tropical conditions and Alewya (2014) respectively. Similar with the present study, nonsignificant effect of season of calving on DO were previously reported by Yosef (2006), Gebeyehu et al. (2007), Alewya (2014) and Haile (2014). Significant effect of year of calving on Cl and DO might be due to variations in feeding and management system, environmental condition, and prevalence of disease from year to year (Alewya, 2014). Similarly, Yosef (2006) reported, most reproductive traits are highly influenced by differences in herd management practices and other environmental factors.

According to Hammoud (2010) significant effect of year of calving on the performance of reproductive traits like $\mathrm{Cl}$ and $\mathrm{DO}$ of dairy cows might be resulted from the changes in feeding and managerial systems and environmental conditions which vary from year to year as well as the differences between years in the quantity and quality of forage available. In the same way, the significant effect of season of calving on reproductive traits might be from the changes in climatic conditions and feeding regimes during different seasons of the year. The result of this study shows that the value of $\mathrm{Cl}$ and DO were declining after the 6th parity. This result is consistent with the study Rege et al. (1994) which concluded that calving interval increases steadily to the 7 th parity.

With regard to this result Bulman and Wood (1980) explained that the general declining trend of the length of $\mathrm{Cl}$ and DO with the advance of parity and the incidence of silent estrus was highest in the primiparous cows and decreased with the advance in parity number and higher nutrient requirement for growth in addition to milk production and maintenance thus delays the onset of postpartum heat. Other study Veerkamp et al. (1995) explained that the decrease in $\mathrm{Cl}$ as parity increase was due to the ability of the animal to recover the uterine environment within shorter periods of time as age increases. During earlier age of lactation the cow utilizes its energy for milk and growth.

The genetic correlation between energy balance and commencement of luteal activity was estimated at -0.6 indicating that negative energy balance leads to shortage of energy for uterine recovery. So at later age $\mathrm{Cl}$ decreases because of requirement of energy is limited to milk production, maintenance and uterine recovery. Significant effect of season of calving on $\mathrm{Cl}$ might be due to green feed availability during short and long rain season than dry season (National Metrology Agency Kombolcha Branch). Longer $\mathrm{Cl}$ in the present study were recorded during short rain season that is followed by long rain season which was 
resulted in longer lactation length because of giving priority to milk than calf rearing and in order to adjust the next season of calving with green feed access.

According to the current study, shorter $\mathrm{Cl}$ was observed during dry season. Various studies explained that reproductive performance of dairy (Sartori et al, 2002) is reduced during hot seasons. The adverse effects of heat stress on follicular growth (Wolfenson et al., 2000), expression of estrous behavior (Trout et al., 1998), superovulatory response (Munro, 1986; Gordon et al., 1987), quality of embryos (Putney et al., 1988), and fertility (Sartori et al., 2002) are well documented in cattle.

In agreement of this fact, the longest $\mathrm{Cl}$ and DO were observed in 2010 and 2000 year of calving respectively and between first and second parity and longest $\mathrm{Cl}$ was during short rain season, while the shortest value of $\mathrm{Cl}$ and DO were recorded in 2008 and 2013 year of calving respectively and at ninth parity and shortest $\mathrm{Cl}$ was during dry season. 
Table 4

Least-squares means ( $L S M \pm S E$ ) for the effect of year of calving, season of calving and parity on calving interval and days open

\begin{tabular}{|c|c|c|c|}
\hline & & Cl (Days) & DO (Days) \\
\hline Source & $\mathrm{N}$ & $\mathrm{LSM} \pm \mathrm{SE}$ & $\mathrm{LSM} \pm \mathrm{SE}$ \\
\hline Overall mean & 360 & $446.1 \pm 6.80$ & $181.7 \pm 7.00$ \\
\hline Year of calving & & ** & * \\
\hline 2000 & 9 & $433.0^{\mathrm{ab}} \pm 58.25$ & $255.0^{\mathrm{a}} \pm 114.21$ \\
\hline 2001 & 10 & $528.1^{a} \pm 45.71$ & $240.5^{a} \pm 45.65$ \\
\hline 2002 & 7 & $461.8^{\mathrm{ab}} \pm 73.55$ & $192.2^{\mathrm{ab}} \pm 75.15$ \\
\hline 2003 & 23 & $434.9^{\mathrm{ab}} \pm 25.33$ & $163.1^{\mathrm{ab}} \pm 24.34$ \\
\hline 2004 & 24 & $428.3^{\mathrm{ab}} \pm 17.44$ & $162.4^{\mathrm{ab}} \pm 17.30$ \\
\hline 2005 & 36 & $415.9^{\mathrm{ab}} \pm 21.80$ & $148.3^{\mathrm{b}} \pm 21.94$ \\
\hline 2006 & 39 & $430.5^{\mathrm{ab}} \pm 22.86$ & $168.9^{\mathrm{ab}} \pm 21.91$ \\
\hline 2007 & 39 & $436.0^{\mathrm{ab}} \pm 19.20$ & $187.8^{\mathrm{ab}} \pm 23.71$ \\
\hline 2008 & 36 & $395.4^{\mathrm{ab}} \pm 15.60$ & $144.3^{b} \pm 14.78$ \\
\hline 2009 & 33 & $457.1^{\mathrm{ab}} \pm 28.28$ & $201.5^{\mathrm{ab}} \pm 28.08$ \\
\hline 2010 & 27 & $528.4^{\mathrm{a}} \pm 22.07$ & $243.0^{\mathrm{a}} \pm 22.57$ \\
\hline 2011 & 24 & $433.1^{\mathrm{ab}} \pm 24.65$ & $155.4^{\mathrm{ab}} \pm 24.76$ \\
\hline 2012 & 38 & $498.9^{\mathrm{ab}} \pm 22.04$ & $222.2^{\mathrm{ab}} \pm 22.37$ \\
\hline 2013 & 14 & $408.7^{\mathrm{ab}} \pm 17.40$ & $142.1^{b} \pm 22.68$ \\
\hline Season of calving & & * & ns \\
\hline Short rain season & 59 & $493.4^{a} \pm 16.59$ & $215.5 \pm 16.07$ \\
\hline Long rain Season & 133 & $442.2^{b} \pm 10.04$ & $184.9 \pm 11.53$ \\
\hline Dry Season & 168 & $432.3^{b} \pm 10.43$ & $166.0 \pm 10.37$ \\
\hline
\end{tabular}

Means followed by the same super script do not differ significantly $(P>0.01)$ or $(P>0.05)$; ** $=$ Highly significant at $(P<0.01) ; *=$ Significant at $(P<0.05) ; N S=$ Non-significant; Parity $=C l$ and DO between parities 1 and 2 for parity 1 and follows the same steps up to parity 9 and $9+$ for parity 9 . 


\begin{tabular}{|c|c|c|c|}
\hline & & Cl (Days) & DO (Days) \\
\hline Parity & & ** & $\star \star$ \\
\hline 1 & 108 & $487.0^{\mathrm{a}} \pm 13.91$ & $226.8^{a} \pm 14.75$ \\
\hline 2 & 84 & $419.7^{\mathrm{ab}} \pm 10.64$ & $155.7^{\mathrm{ab}} \pm 12.09$ \\
\hline 3 & 62 & $429.2^{\mathrm{ab}} \pm 15.50$ & $163.9^{\mathrm{ab}} \pm 15.06$ \\
\hline 4 & 46 & $447.1^{\mathrm{ab}} \pm 18.74$ & $172.3^{\mathrm{ab}} \pm 17.97$ \\
\hline 5 & 29 & $421.2^{\mathrm{ab}} \pm 24.21$ & $160.2^{\mathrm{ab}} \pm 23.31$ \\
\hline 6 & 14 & $441.2^{\mathrm{ab}} \pm 38.16$ & $182.5^{\mathrm{ab}} \pm 33.72$ \\
\hline 7 & 9 & $439.6^{\mathrm{ab}} \pm 48.01$ & $184.7^{\mathrm{ab}} \pm 53.67$ \\
\hline 8 & 5 & $393.5^{\mathrm{ab}} \pm 17.08$ & $109.4^{\mathrm{ab}} \pm 14.28$ \\
\hline 9 & 3 & $339.0^{b} \pm 00$ & $68.0^{\mathrm{b}} \pm 0.00$ \\
\hline \multicolumn{4}{|c|}{$\begin{array}{l}\text { Means followed by the same super script do not differ significantly }(P>0.01) \text { or }(P>0.05) ; * *=\text { Highly } \\
\text { significant at }(P<0.01) ; *=\text { Significant at }(P<0.05) ; N S=\text { Non-significant; } P \text { arity }=C l \text { and Do between } \\
\text { parities } 1 \text { and } 2 \text { for parity } 1 \text { and follows the same steps up to parity } 9 \text { and } 9+\text { for parity } 9 \text {. }\end{array}$} \\
\hline
\end{tabular}

The mean $\mathrm{Cl}$ and DO were $446.1 \pm 6.79$ and $181.7 \pm 7$ days with coefficient of determination $\left(R^{2}\right) 0.19$ and 0.16 and the result were range from 300 to 897 days and from 39 to 675 days, respectively. The result of the present study for $\mathrm{Cl}$ was higher than the recommended $\mathrm{Cl}$ values of 365-385 days (Peters, 1984). The mean value of $\mathrm{Cl} 446.1$ days in presented study was longer than 433.0, 399 and 419.9 days as reported by Gader et al. (2007) for Holstein-Friesian cows in Sudan, Gwaza et al. (2007) for Holstein-Friesian cows in Cameron and Buaban et al. (2015) for Holstein-Friesian cows in Tropics respectively. Similarly, mean average value of 181.7 days for DO in the current study was longer than 174.0,167.0,148.0, 134.9 and 134.8 days as reported by Yosef (2006), Gader et al. (2007), Million et al. (2010), Buaban et al. (2015) and Mengistu et al. (2016) for Holstein-Friesian cows in Ethiopia, Sudan, Ethiopia, Tropics and Ethiopia respectively.

The current result of $\mathrm{Cl}$ was in concordance with 445 and 445.4 days reported by Million et al. (2010) for HF dairy cows in Ethiopia and Ibrahim et al. (2012) for Homebred HF cows under hot climates (Tropics) respectively. In the same way, nearly similar results with the current result of DO were 177.0 days reported by Gebeyehu et al. (2007) for Friesian cows in Holleta dairy farm, Ethiopia. Longer values of $\mathrm{Cl}$ compared to the present study were exhibited as 452.9, 470.0 and 513.4 days on the study Yosef (2006), Alewya (2014) and Haile (2014) for Holstein-Friesian dairy cows in Holleta dairy farms, in Holleta bull dam station and Genesis dairy farms and in Alage dairy farm, Ethiopia respectively. Similarly, longer values of DO compared to the current study for Holstein-Friesian dairy cows in Ethiopia were reported as 206.0, 
285.0, 202.0, and 208.8 days by Besufekad (2008) in Holleta bull dam station, Gizaw et al. (2011) in sub humid environments of Bako, Alewya (2014) in Holleta bull dam station and Genesis dairy farms and Haile (2014) in Alage dairy farm, Ethiopia respectively. These differences might be due to breeding, feeding and health management differences and also due to environmental differences as per the farm locations and also inefficient heat detection, silent heat of heifers and bulls' breeding efficiency may also cause variation in $\mathrm{Cl}$ and DO results (Alewya, 2014). Longer $\mathrm{Cl}, \mathrm{DO}$ and NSC might be resulted from feeding problem, silent estrus and lack of proper heat detection (Belay et al., 2012). The longer $\mathrm{Cl}$ values might be due to higher NSC and DO and might be from extended LL and from poor management and inadequate breeding service (Gebeyehu et al., 2007). Locations of the farm may also resulted by longer $\mathrm{Cl}$ and DO values; since the farm is found in the Borkena valley which is expected as not more favorable for exotic breed rearing because of its hot temperature.

\section{Number of Service per Conception (NSC)}

The significant effect of year of calving on NSC were in agreement with the previous reports of Yosef (2006) in Holleta dairy farm, Besufekad (2008) in Holleta bull dam station, Reyes et al. (2010) in the tropics, Haile (2014) in Alage dairy farm and Mengistu et al. (2016) in Ardaita dairy farm, in Ethiopia. Similarly significant effect of parity on NSC were in agreement with the previous reports of Yosef (2006) in Holleta dairy farm, Gebeyehu et al. (2007) in Stella Private Dairy Farm, Besufekad (2008) in Holleta bull dam station, Million et al. (2010) in Holleta, Stella and Dinkity dairy farms and Alewya (2014) in Holleta bull dam station and Genesis dairy farms, in Ethiopia. To the contrary, non-significant effects of year of calving on NSC were previously reported by Million et al. (2010) and Alewya (2014) and non-significant effect of parity on NSC were also reported by Asseged and Birhanu (2004), Haile (2014) and Mengistu et al. (2016). Non-significant effects of season of calving in this study were similar to the previous study of Yosef (2006), Gebeyehu et al. (2007), Million et al. (2010) and Alewya (2014). Unlikely to the present study, significant effect of season of calving on NSC were previously reported by Besufekad (2008), Reyes et al. (2010) and Haile (2014). The longest value for NSC was recorded in 2001 year of calving and at seventh parity while, shortest NSC were recorded in 2000 year of calving and at first parity (Table 5). Significant effect of year of calving on NSC might be from variation in breeding system (Alewya, 2014), health and feeding management and it might be also from climatic change, disease prevalence and lactation length (Abdel and Alemam, 2008). Significant effect of parity on NSC might be from age difference (Motlagh et al., 2013) and reproductive tract infections. The longest and shortest results of NSC respectively at seventh and first parity might be from age difference. As age increase, exposure of animals to reproductive tract diseases may also be increase hence, production of fertile egg will become decrease and cows will unable to conceive at a single service.

Statistically non-significant $(P>0.05)$ effect of season of calving on NSC was might be due to similar breeding practice from season to season in the year and might be covered by fairly regular feeding management activities supported by use of rotation grazing and carry and cut system in addition to formulated feed. 
Table 5

Least-squares means $(\mathrm{LSM} \pm \mathrm{SE}$ ) for the effect of year of calving, season of calving and parity on number of service per conception

\begin{tabular}{|c|c|c|}
\hline & & NSC (Ratio) \\
\hline Source & $\mathrm{N}$ & $\mathrm{LSM} \pm \mathrm{SE}$ \\
\hline Overall mean & 483 & $1.6 \pm 0.05$ \\
\hline Year of calving & & * \\
\hline 2000 & 9 & $1.0^{\mathrm{b}} \pm 00$ \\
\hline 2001 & 10 & $2.1^{\mathrm{a}} \pm 0.58$ \\
\hline 2002 & 7 & $1.4^{\mathrm{ab}} \pm 0.20$ \\
\hline 2003 & 25 & $1.6^{\mathrm{ab}} \pm 0.22$ \\
\hline 2004 & 25 & $1.4^{\mathrm{ab}} \pm 0.21$ \\
\hline 2005 & 42 & $2.1^{\mathrm{a}} \pm 0.20$ \\
\hline 2006 & 43 & $1.6^{\mathrm{ab}} \pm 0.18$ \\
\hline 2007 & 46 & $1.6^{\mathrm{ab}} \pm 0.11$ \\
\hline 2008 & 45 & $1.5^{\mathrm{ab}} \pm 0.15$ \\
\hline 2009 & 49 & $1.3^{\mathrm{ab}} \pm 0.13$ \\
\hline 2010 & 39 & $1.3^{\mathrm{ab}} \pm 0.13$ \\
\hline 2011 & 26 & $1.6^{\mathrm{ab}} \pm 0.24$ \\
\hline 2012 & 47 & $1.7^{\mathrm{ab}} \pm 0.16$ \\
\hline 2013 & 35 & $2.0^{\mathrm{a}} \pm 0.25$ \\
\hline 2014 & 35 & $1.3^{\mathrm{ab}} \pm 0.11$ \\
\hline Season of calving & & ns \\
\hline Short rain season & 79 & $1.7 \pm 0.13$ \\
\hline Long rain Season & 177 & $1.4 \pm 0.07$ \\
\hline Dry Season & 227 & $1.7 \pm 0.08$ \\
\hline
\end{tabular}

Means followed by the same letter do not differ significantly $(P>0.01)$ or $(P>0.05)$; $*$ * Highly significant at $(P<0.01) ; *$ Significant at $(P<0.05) ;$ NS = Non-significant 


\begin{tabular}{|c|c|c|}
\hline & & NSC (Ratio) \\
\hline Parity & & $\star \star$ \\
\hline 1 & 123 & $1.3^{b} \pm 0.06$ \\
\hline 2 & 108 & $1.7^{\mathrm{ab}} \pm 0.11$ \\
\hline 3 & 84 & $1.6^{\mathrm{ab}} \pm 0.12$ \\
\hline 4 & 63 & $1.7^{\mathrm{ab}} \pm 0.11$ \\
\hline 5 & 45 & $1.8^{\mathrm{ab}} \pm 0.18$ \\
\hline 6 & 28 & $1.7^{\mathrm{ab}} \pm 0.24$ \\
\hline 7 & 15 & $2.3^{a} \pm 0.50$ \\
\hline 8 & 9 & $1.7^{\mathrm{ab}} \pm 0.55$ \\
\hline 9 & 8 & $1.4^{b} \pm 0.24$ \\
\hline
\end{tabular}

In this study; the mean of NSC was $1.6 \pm 0.05$ with coefficient of determination $\left(R^{2}\right)$ of 0.12 and the data was ranges from 1 to 6 . The mean value 1.6 for NSC in the present study was longer than previous studies of 1.4 reported by Haile (2014) in Alage dairy farm and Mengistu et al. (2016) in Ardaita dairy farm for Holstein-Friesian cows. The current results of NSC were in agreement with 1.6 previously reported by Buaban et al. (2015) for Holstein-Friesian dairy cows in Thailand and nearly similar to the previous findings of 1.7, 1.8 and 1.7 reported by Gebeyehu et al. (2007) in Stella Private Dairy Farm, Million et al. (2010) in Holleta, Stella and Dinkity dairy farms and Gizaw et al. (2011) in Bako dairy farm for Holstein-Friesian dairy cows respectively. Longer values of NSC for Holstein-Friesian dairy cows as compared to the current study were 2.0, 2.1 and 2.1 identified by Yosef (2006) in Holleta dairy farms, Besufekad (2008) in Holleta bull dam station and Alewya (2014) In Holleta bull dam station and Genesis dairy farms respectively.

The differences might be due to variations in the breeding, feeding (insufficient nutrition) and health care management, environment (farm locations) and fertility status of the breeding cows and bulls' breeding efficiency, semen fertility rate, reproductive health status and limitations in heat detection might be additional source of variation (Alewya, 2014). These differences also might be due to variations in the management, environment and fertility status of the breeding cows (Ibrahim, 2012). Breeding system used the reproductive health status of the animal, the management and feeding practices in a farm and natural service bulls may also be the source of variation in NSC (Tewodros, 2008). 


\section{Lactation Length (LL) and Adjusted 305 Days of Milk Yield (305-dMY)}

Significant effects of year of calving on 305-dMY were reported by Yosef (2006) in Holleta dairy farm and significant effect of year of calving and parity on 305-dMY were reported by Wondossen et al. (2015) in Holleta bull dam station but, Yosef (2006) was reported non-significant effect of season of calving and parity on 305-dMY.

Maximum 305-dMY was recorded in 2002, during short rain season and at fifth parity while, minimum 305-dMY was recorded in 2012, during long rain season and at ninth parity (Table 6). Maximum 305-dMY in 2002 year of calving might be due to management, less disease prevalence, because of lowest relative humidity and relatively low rainfall during the year (National Metrology Agency Kombolcha Branch) that enforces use of more irrigation and confined feeding and it might be from HF blood level that might be optimum to the specified environment and management applied in the farm and it might be also from better skills of milkers. Minimum 305-dMY recorded in 2012 year of calving might be resulted from highest temperature in the present study area (National Metrology Agency Kombolcha Branch), hence might be resulted in improper feed and water access.

The maximum result for 305-dMY during short rain seasons might be resulted from green feed access due to longer rain season following the short rain season and the minimum result during long rain season calving might be from the shortage of green feed access due to dry season following the long rain season. The result of this study show that milk yield were increased from parity $1-5$ and then milk yield declined. As the study Ombura et al. (2007) described the decline is due to decline in body condition and degeneration of the body system over the recurring pregnancies. It will depend on whether the cow is able to maintain the condition to a subsist level. Other study Keown et al. (1986) also described that the milk yield was lower in early parities because the feed that was provided to the heifers was also channeled to their growth as they were still growing. As the parities proceeded, milk yield increased because the feed requirements for growth were declining.

According to the present study; LL was significantly affected by parity but not significantly affected by year of calving and season of calving. The significant effect of parity on LL was in agreement with the previous reports of Alewya (2014) in Holleta bull dam station and Genesis dairy farms and Wondossen et al. (2015) in Holleta bull dam station, in Ethiopia. The studies Msanga et al. (2000); Epaphras et al. (2004) explained that genetic background, climate, diseases, feeding, year and season of calving have been reported to affect milk production and lactation length. Significant effect of parity on LL might be from difference in production set up and management systems (Alewya, 2014).

Shorter LL during the advanced parity (ninth parity) might be from age difference of the breeding animals that $\mathrm{LL}$ becomes shorter with in older age due to shorter $\mathrm{Cl}$ and $\mathrm{DO}$ during advanced parity. During earlier age of lactation the cow utilizes its energy for milk and growth (Veerkamp et al., 1995). Non-significant effects of year of calving on LL in agreement to the current study was reported by Ibrahim et al. (2012) in 
the tropics and in the same way non-significant effect of season of calving on LL as the current study was also reported by Ibrahim et al. (2012), Alewya (2014) in Holleta bull dam station and Genesis dairy farms and Haile (2014). To the contrary, non-significant effects of parity on LL were previously reported by Ibrahim et al. (2012) and Haile (2014) in Alage dairy farm. Significant effects of year of calving on LL were reported by Alewya (2014) and Haile (2014) and also significant effects of season of calving on LL were reported by Wondossen et al. (2015). 
Table 6

Least-squares means (LSM $\pm \mathrm{SE}$ ) for the effect of year of calving, season of calving and parity on lactation length and adjusted 305 days of milk yield

\begin{tabular}{|c|c|c|c|}
\hline & & LL (Days) & 305-dMY (Liters) \\
\hline Source & $\mathrm{N}$ & $\mathrm{LSM} \pm \mathrm{SE}$ & $\mathrm{LSM} \pm \mathrm{SE}$ \\
\hline Overall mean & 447 & $328.3 \pm 5.50$ & $2305.2 \pm 32.15$ \\
\hline Year of calving & & NS & ** \\
\hline 2000 & 8 & $258.9 \pm 36.51$ & $2399.7^{\mathrm{bcde}} \pm 181.28$ \\
\hline 2001 & 10 & $322.6 \pm 27.88$ & $2728.9^{\mathrm{abc}} \pm 266.47$ \\
\hline 2002 & 7 & $312.2 \pm 33.33$ & $3285.0^{a} \pm 290.49$ \\
\hline 2003 & 25 & $342.9 \pm 16.23$ & $2468.9^{\text {bcde }} \pm 145.13$ \\
\hline 2004 & 24 & $327.3 \pm 12.12$ & $2672.5^{\mathrm{abcd}} \pm 131.56$ \\
\hline 2005 & 40 & $291.6 \pm 11.32$ & $2430.0^{\mathrm{bcde}} \pm 89.83$ \\
\hline 2006 & 43 & $310.8 \pm 16.31$ & $2643.6^{\mathrm{abcd}} \pm 121.67$ \\
\hline 2007 & 41 & $316.7 \pm 16.54$ & $2283.1^{\text {bcde }} \pm 116.92$ \\
\hline 2008 & 41 & $331.6 \pm 17.57$ & $2425.3^{\text {bcde }} \pm 103.44$ \\
\hline 2009 & 42 & $378.0 \pm 22.85$ & $2307.0^{\text {bcde }} \pm 90.59$ \\
\hline 2010 & 31 & $332.2 \pm 26.39$ & $2146.5^{\mathrm{cde}} \pm 106.79$ \\
\hline 2011 & 25 & $308.7 \pm 16.15$ & $2079.9^{\text {cde }} \pm 100.67$ \\
\hline 2012 & 44 & $336.1 \pm 22.10$ & $1908.8^{\mathrm{e}} \pm 78.90$ \\
\hline 2013 & 33 & $343.3 \pm 19.99$ & $1984.1^{d e} \pm 99.78$ \\
\hline 2014 & 33 & $332.8 \pm 27.10$ & $1962.6^{\mathrm{de}} \pm 66.24$ \\
\hline Season of calving & & NS & * \\
\hline Short rain season & 75 & $341.7 \pm 12.18$ & $2459.3^{a} \pm 78.67$ \\
\hline Long rain Season & 160 & $317.5 \pm 9.11$ & $2195.1^{\mathrm{b}} \pm 49.11$ \\
\hline Dry Season & 212 & $332.0 \pm 8.24$ & $2333.8^{\mathrm{ab}} \pm 48.75$ \\
\hline Parity & & * & ** \\
\hline
\end{tabular}




\begin{tabular}{|ccll|}
\hline & & LL (Days) & 305-dMY (Liters) \\
\hline 1 & 121 & $358.2^{\mathrm{a}} \pm 10.73$ & $2080.1^{\mathrm{b}} \pm 47.04$ \\
\hline 2 & 99 & $319.8^{\mathrm{ab}} \pm 12.13$ & $2231.4^{\mathrm{ab}} \pm 68.70$ \\
\hline 3 & 75 & $314.3^{\mathrm{ab}} \pm 11.34$ & $2497.2^{\mathrm{ab}} \pm 84.26$ \\
\hline 4 & 59 & $312.5^{\mathrm{ab}} \pm 15.39$ & $2415.8^{\mathrm{ab}} \pm 92.73$ \\
\hline 5 & 40 & $322.4^{\mathrm{ab}} \pm 14.66$ & $2568.6^{\mathrm{a}} \pm 118.46$ \\
\hline 7 & 24 & $321.1^{\mathrm{ab}} \pm 31.53$ & $2484.4^{\mathrm{ab}} \pm 153.64$ \\
\hline 9 & 14 & $306.2^{\mathrm{ab}} \pm 22.41$ & $2338.0^{\mathrm{ab}} \pm 160.37$ \\
\hline & 8 & $324.5^{\mathrm{ab}} \pm 21.13$ & $2166.8^{\mathrm{ab}} \pm 137.90$ \\
\hline
\end{tabular}

Means followed by the same letter do not differ significantly $(P>0.01)$ or $(P>0.05)$; $* *=$ Highly significant at $(P<0.01) ; *$ = Significant at $(P<0.05) ; N S=$ Non-significant

The mean LL and 305-dMY were 328.3 \pm 5.50 days and $2305.2 \pm 32.15$ litters with coefficient of determination $\left(R^{2}\right)$ of 0.09 and 0.28 and the records were ranges from 100 to 750 days and from 1100 to 4148 litter, respectively. The mean value 328.3 days for $L L$ in the present study was longer than 294.0, 306.0 and 264.6 days of the previous study reported by Gader et al. (2007) for HF dairy cows in Sudan, Alewya (2014) and Haile (2014) for HF dairy cows in Holleta bull dam station and Genesis dairy farms and in Alage dairy farm, in Ethiopia respectively.

The current result of LL was nearly similar with 319.0 days reported by Wondwossen et al. (2015) for Holstein-Friesian dairy cows in Holleta Bull Dam Station in Ethiopia. Longer values of LL compared to the present study were 349.0 and 376.7 days reported by Ibrahim et al. (2012) respectively for Homebred and Imported HF cows in Tropics. Similarly, greater 305-dMY results compared to the current study for Holstein-Friesian cows with 3349.1, 3084.0 and 3604.0 litters were reported by Yosef (2006) in Holleta dairy farms, Gebeyehu et al. (2014) and Wondwossen et al. (2015) in Holleta Bull Dam Station, in Ethiopia.

The differences milk yield and lactation length in different farms of the same breed might be due to herd management with respect to feed, disease and other environmental differences than genotype differences. Environmental factors tend to obscure the animal's true genetic ability. In this regard, Missanjo et al. (2011) observed that selection within the best environment allowed better gene expression and selection response were therefore improved. Hence, environmental variance, which by definition embraces all variation of non-genetic origin, is a source of error that reduces precision in genetic studies. 


\section{Conclusion}

The hypothesis that non-genetic factors (year of birth, year of calving, season of calving and parity) except season of birth have significant influence on reproductive and productive performance traits was accepted in the present study. Knowledge on the effect of these non-genetic factors on reproduction and production traits is important and it would help in making management decisions and selection practice for improvement of the dairy animals in the study area. Difference in genetic performance and its interaction with the production environment were found as a cause to the variation in reproduction and production performance of dairy cows and the present study has tested this assumption on HF dairy cows in the specified study area.

\section{Abbreviations}

305-dMY Milk Yield at 305 Days

AFC Age at First Calving

AFS Age at First Service

BP Bovine Pasteurollosis

CBPP Contagious Bovine Pleuro pneumonia

Cl Calving Interval

DO Days Open

DP Dry Period

FMD Foot and Mouth Disease

HF Holstein Friesian

LL Lactation Length

LMY Lactation Milk Yield

LSD Lumpy Skin Disease

NSPC Number of Services Per-Conception

PL Pregnancy Length

SAS Statistical Analysis System 


\section{Declarations}

Ethics approval and consent to participate:- I declare and affirm that this research is my own work. I have followed all ethical and technical principles of scholarship in the preparation, data collection, data analysis and compilation of the research. Any scholarly matter that is included in the research has been given recognition through citation.

Consent for publication:- There is no some one's image, photo or any figure that needs conformation.

Availability of data and material:- The source of data all compiled in this research ware collected from the records of the farm the is listed on the research site. Therefore all data and materials used in the research were found in my hand and I can deliver it at any time if required.

Competing interests:- No competing interest at all from both principal and co-authors either in terms of financial and non-financial aspects of the research.

Funding:- Wollo University, Dessie Ethiopia was the source of the research fund excluding of publication fee.

Authors' contributions:- Dr. Yosef Tadesse and Dr. Aynalem Haile have fully participating for this research work, specially in encouragement, valuable guidance for research write up, constructive comments at each phase of the research and excellent cooperation and visited the research site.

Acknowledgements:- My deepest acknowledgment is to my friend Wondossen Kebede (PhD candidate at a time in Haramaya University) for his valuable guidance of statistical software data processing.

Authors' information (optional): the information/profile of the authors is listed in the title page

Footnotes:- The research is part of MSc thesis worked in Haramaya University.

\section{References}

Abdel Gader, A. Z., Ahmed, M. K. A., Musa, L. M. A. and Peters, K. J. 2007. Milk yield and reproductive performance of Friesian cows under Sudan tropical conditions. Archiva Tierzucht Dummerstorf, 50(2): 155-164.

Abdel Rahman, I. M. K. and T.A. Alemam. 2008. Reproductive and productive performance of Holstein Friesian cattle under tropical conditions with special reference to Sudan- a review. Agricultural Review, 29 (1):68-73.

Alewya Heyredin. 2014. Comparative study of reproductive and productive performance of Holstein Friesian dairy cows at Holleta bull dam station and Genesis farms. MSc Thesis Addis Ababa University, Addis Ababa, Ethiopia. 
Amene Fekadu, Tesfu Kassa and Kelay Belihu. 2011. Study on reproductive performance of HolsteinFriesian dairy cows at Alage dairy farm, rift valley of Ethiopia. Tropical Animal Health Production, 43, 581586.

Asseged Bogale and Birhanu Mamo. 2004). Survival analysis of calves and reproductive performance of cows in commercial dairy farms in and around Addis Ababa, Ethiopia. Tropical Animal Health Production, 36: $663-672$.

Avendaño Reyess, L., Fuquay, J. W., Moore, R. B., Liu Z., Clark, B. L. and Vierhout, C. 2010. Relationship between accumulated heat stress during the dry period, body condition score, and reproduction parameters of Holstein cows in tropical conditions. Tropical Animal Health Production, 42: 265-273.

Belay Duguma, Yisehak Kechero and G.P.J. Janssens. 2012. Productive and Reproductive Performance of Zebu X Holstein-Friesian Crossbred Dairy Cows in Jimma Town, Oromia, Ethiopia. Global Veterinarian 8 (1): 67-72.

Belete Anteneh, 2006. Studies on cattle milk and meat production in Fogera Woreda: production systems, constraints and opportunities for development. MSc Thesis Awassa University, Awassa, Ethiopia

Besufekad Jufar. 2008. Reproductive and lactation performance of Holstein -Friesian cows at Holleta bull dam station. MSc Thesis, Addis Ababa University, Addis Ababa, Ethiopia.

Buaban, S., M. Duangjinda, M. Suzuki, Y. Masuda, J. Sanpote, and K. Kuchida. 2015. Genetic analysis for fertility traits of heifers and cows from smallholder dairy farms in a tropical environment.

Bulman, D. C., and P. D. P. Wood. 1980. Abnormal patterns of ovarian activity in dairy cows and their relationship with reproductive performance. Journal of Animal Production, 30:177-188.

Epaphras, A., Karimuribo, E. D. and Msellem, S. N. 2004. Effect of season and parity on lactation of crossbred Ayrshire cows reared under coastal tropical climate in Tanzania. Livestock Research Rural Development, 16(6).

\section{http://www.Irrd.org//rrd16/6/epap16042.htm.}

Gebeyehu Goshu. 2005. Breeding efficiency, lifetime lactation and calving performance of Friesian-Boran crossbred cows at Cheffa farm, Ethiopia. Livestock Research for Rural Development 17(7).

Gebeyehu Goshu, Kelay Belihu and Abebe Berihun. 2007. Effect of Parity, Season and Year on Reproductive Performance and Herd Life of Friesian Cows at Stella Private Dairy Farm, Ethiopia. Livestock research for Rural development 19(7) 2007.

Gebeyehu Goshu, Harpal, S., Karl-Johan, P. and Nils, L. 2014. Heritability and correlation among first lactation traits in Holstein Friesian cows at Holeta Bull Dam Station, Ethiopia. Academic journals, 
Gizaw Kebede, Mulugeta Kebede, Tesfaye Midekssa and Sisay Eshetu. 2011. Comparative reproductive performance of Horro (Zebu) with Horro x Friesian and Horro x Jersey females in sub humid environments of Bako. Livestock Research Rural Development, 23 (8). http://www.Irrd.org/Irrd23/8/Kebe23171.htm.

Gordon, I., Boland, MP., McGovern, H. and Lynn, G. 1987. Effect of season on superovulatory responses and embryo quality in Holstein cattle in Saudi Arabia. Theriogenology 1987; 27:231.

Gwaza, D S., Okwori, A I., Abu, A H. and Fombah, E M. 2007. A retrospective study on reproductive and dairy performance of Holstein Friesian on zero grazing in the western highland regions of Cameroon. Livestock Research for Rural Development, 19 (4) 2007. http://www.Irrd.org/Irrd19/4/gwaz19057.htm.

Haile Berihulay. 2014. Evaluation of Reproductive Performance of Holstein Friesian Dairy Cows at Alage Agricultural Technical Vocational Educational Training College Dairy Farm, South Western Ethiopia. MSc Thesis, Haramaya University, Haramaya, Ethiopia.

Hammoud, M. H., El-Zarkouny, S. Z. and Oudah, E. Z. M. 2010. Effect of sire, age at first calving, season and year of calving and parity on reproductive performance of Friesian cows under semiarid conditions in Egypt. Archiva Zoology Technica, 13: 60-82.

Hunduma Dinka. 2013. Reproductive performance of crossbred dairy cows under smallholder condition in Ethiopia. African Journal of Dairy Farming and Milk Production Volume1(5), pp. 101-103, December, 2013.

Ihlam Ibrahim Eid, Mohamed Omer Elsheikh and Ibrahim A/Salam Yousif. 2012. Estimation of Genetic and Non-Genetic Parameters of Friesian Cattle under Hot Climate. Journal of Agricultural Science Volume 4, No. 4; 2012.

Kelay Belihu. 2002. Analyses of dairy cattle breeding practices in selected areas of Ethiopia. PhD Dissertation, Humboldt-University, Berlin.

http://edoc.hu-berlin.de/dissertationen/desta-kelay-belihu-2.

Keown JF, Everett RW, 1986. Effect of days carried calf, days dry and weight of $1^{\text {st }}$ calf heifers on milk yield. J Dairy Sci 1986, 69: 1891. 10.3168/jds.S0022-0302(86)80615-4.

Khalid, J., Ghulam, M. and Pervez, A. 2001. Heritability estimates of some productive traits in Sahiwal cattle. Pakistan Veterinary Journal, 21(3): 2001.

Mengistu Desta, Wondimagegn, K. and Demisash, M. 2016. Reproductive Performance Evaluation of Holstein Friesian and Their Crosses with Boran Cattle Breeds in Ardaita Agricultural Technical Vocational Education Training College Dairy Farm, Oromia Region, Ethiopia. 
Million Tadesse, Thiengtham, J, Pinyopummin, A. and Prasanpanich, S. 2010. Productive and reproductive performance of Holstein Friesian dairy cows in Ethiopia. Livestock Research for Rural Development, Volume 22, (2) article number 34(34).http://www.Irrd.org/Irrd22/2/tade22034.htm.

Missanjo, E. M., Imbayarwo-Chikosi, V. E. and Halimani, T.E. 2011. Environmental factors affecting milk, fat and protein yields in Jersey cattle in Zimbabwe. Tropical Animal Health Production, 2011, 43: 665667.

Motlagh, M. K., Roohani, Z., Shahne, A. Z. and Moradi, M. 2013. Effects of age at calving, parity, year and season on reproductive performance of dairy cattle in Tehran and Qazvin Provinces, Iran. Research Opin. Animal Veterinary Science, 3(10): 337-342.

Msanga, Y.N., Bryant, M.J., Rutam, I.B., Minja, F.N. and Zylstra, L. 2000. Effect of environmental factors and of the proportion of Holstein blood on the milk yield and lactation length of crossbred dairy cattle on smallholder farms in north-east Tanzania. Tropical Animal Health Production, 32, 23-31.

Munro, R. K. 1986. The superovulatory response of Bos-Taurus and B. Indicus cattle following treatment with follicle stimulating hormone and progesterone. Animal Reproduction ScienceVolume 11, 1986, Pages 91-97.

Ombura, J, Wakhungu, J. W., Mosi R. O. and Amimo, J. O. 2007. An assessment of the efficiency of the dairy bull dam selection methodology in Kenya. Livestock Research for Rural Development. Volume 19, Article, 10, Retrieved July 20, 2014.http://www.Irrd.org/Irrd19/1/ombu19010.htm.

Ozhan, M., Tiizcmen, N. and Yanar, M. 2001. Buyukbas hayvan yetistirme. Ucuncii baski. Atatiirk Universitesi Ziraat Fakiiltesi Ofset Tesisi, Erzurum.

Parker Chevell. 2008. Creating the perfect data grid using the SAS output delivery system. Proceedings of the SAS Global Forum 2008 Conference. Cary, NC: SAS Institute Inc. www.sas.com/proceedings/forum2008/258-2008.pdf.

Peters, A.R. 1984. Reproductive activity of the cow in the post-partum period. Factors affecting the length of the post-partum acyclic period. British Veterinary Journal, 140, 74-84.

Putney, D. J., J. R. Malayer, T. S. Gross, W. W. Thatcher, P. J. Hansen and M. Drost. 1988. Heat StressInduced Alterations in the Synthesis and Secretion of Proteins and Prostaglandins by Cultured Bovine Conceptuses and Uterine Endometrium. Biology of Reproduction, Volume 39, Issue 3, 1 October 1988, Pages 717-728. https://doi.org/10.1095/biolreprod39.3.717.

Rege JEO, Aboagye, G. S., Akah, S. and Ahunu, B. K. 1994. Crossbreeding Jersey with Ghana Shorthorn and Sokoto Gudali cattle in a tropical environment; additive and heterotic effects for milk production, reproduction and calf growth traits. Journal of Animal Production, 59: 21-29. 
Sang Hyon, O.H. 2003. Estimation of genetic parameters for Boar semen traits. PhD. Dissertation submitted to the Faculty of North Carolina State University, Department of Animal Science, Raleigh.

Sartori, R., R. Sartor-Bergfelt, S.A. Mertens, J.N. Guenther, J.J. Parrish and M.C. Wiltbank. 2002. Fertilization and Early Embryonic Development in Heifers and Lactating Cows in Summer and Lactating and Dry Cows in Winter. November 2002Volume 85, Issue 11, Pages 2803-2812.

Tewodros Bimerew. 2008. Assessment of Productive and Reproductive Performance of Indigenous and Crossbred Cattle under Smallholder Management System in North Gondar, Amhara Region. MSc Thesis, Mekele University, Mekele, Ethiopia.

Trout, JP, McDowell, LR and Hansen, PJ. 1998. Characteristics of the oestrous cycle and antioxidant status of lactating Holstein cows exposed to stress. Journal of Dairy Science, 1998; 81:1244-50.

Veerkamp, R.F., G.C. Emmans, A.R. Cromie and G. Simm. 1995. Variance components for residual food intake in dairy cows. Livestock Production Science, 41 (1995), pp. 111-120.

Wiggans, G.R. and F.N. Dickinson. 1985. National Cooperative Dairy Herd Improvement Program (NCDHIP). A Cooperative effort of Dairy producers, Breed associations, Al organizations, Cooperative Extension, USDA-Extension Service-Agricultural Research Service.

Wolfenson, D., Roth, Z. and Meidan, R. 2000. Impaired reproduction in heat stressed cattle; basic and applied aspects. Animal Reproduction Science 60, 535-547.

Wondossen Ayalew, Mohammed Aliy and Enyew Negussie. 2015. Milk production performance of Holstein Friesian dairy cows at Holleta Bull Dam Farm, Ethiopia. Livestock rsearch for rural development, 27(9).

Yosef Tadesse. 2006. Genetic and Non-Genetic Analysis of Fertility Traits in Holleta and Ada'a Berga Dairy Herds. MSc Thesis, Haramaya University, Haramaya, Ethiopia.

\section{Figures}




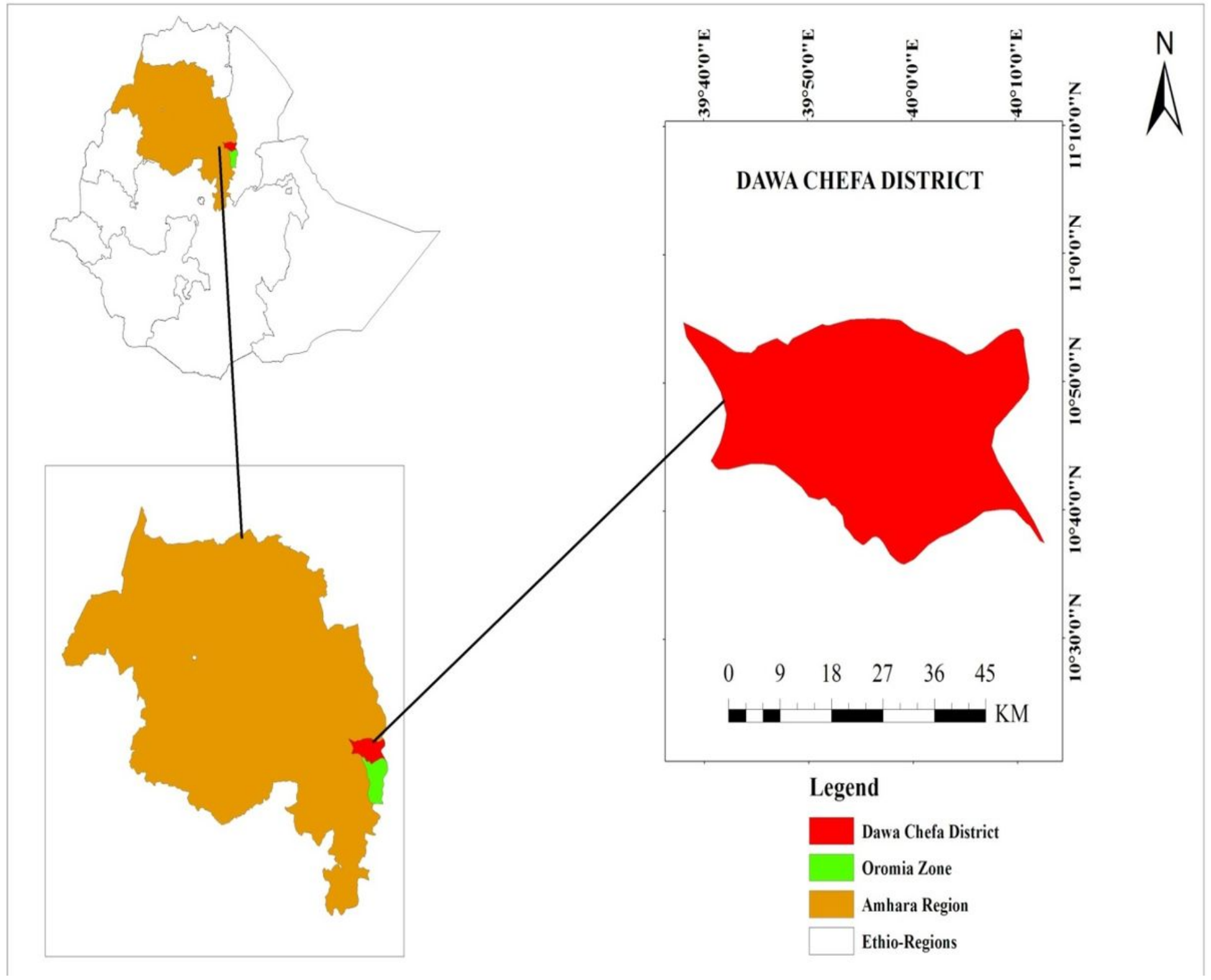

\section{Figure 1}

Map of Dawa Cheffa District, South Wollo Zone, Ethiopia. Note: The designations employed and the presentation of the material on this map do not imply the expression of any opinion whatsoever on the part of Research Square concerning the legal status of any country, territory, city or area or of its authorities, or concerning the delimitation of its frontiers or boundaries. This map has been provided by the authors. 